\title{
Serum Glucose Measurement
}

National Cancer Institute

\section{Source}

National Cancer Institute. Serum Glucose Measurement. NCI Thesaurus. Code C61027.

A quantitative measurement of the amount of glucose present in a sample of serum. 